\title{
O Paciente com Infecção de Vias Aéreas Superiores. Quando Anestesiar?*
}

\author{
Patient with Upper Airway Infectious Disease. \\ When to Induce Anesthesia?
}

Eliana Marisa Ganem, TSA ${ }^{1}$; Norma Sueli Pinheiro Módolo, TSA ${ }^{1}$; Yara Marcondes Machado Castiglia, TSA ${ }^{2}$

\section{RESUMO}

Ganem EM, Módolo NSP, Castiglia YMM - O Paciente com Infecção de Vias Aéreas Superiores. Quando Anestesiar?

JUSTIFICATIVA E OBJETIVOS - Anestesiar, com segurança, a criança com infecção de vias aéreas superiores (IVAS) constitui um dos grandes desafios do anestesiologista. A finalidade deste artigo é discutir a validade de anestesiar e quando anestesiar a criança com IVAS.

CONTEÚDO - Estão ressaltados a importância da história clínica na investigação pré-operatória, os fatores que contribuem para o aparecimento de complicações no per e no pós-operatório, assim como o tipo de cirurgia e a técnica anestésica que favorecem estas complicações.

CONCLUSÕES - O conhecimento das alterações no trato respiratório que acontecem após IVAS, da importância da avaliação correta da gravidade dos sintomas, dos fatores que podem contribuir para o aparecimento de complicações e da melhor técnica anestésica possibilita a seleção de pacientes com menor risco de desenvolver complicações no período per-operatório.

Unitermos: ANESTESIA, Pediátrica; DOENÇAS: infeção de vias aéreas superiores

\section{SUMMARY}

Ganem EM, Módolo NSP, Castiglia YMM - Patient with Upper Airway Infectious Disease. When to Induce Anesthesia?

BACKGROUND AND OBJECTVES: Anesthesia in children with upper airway infection (UAI) is a major challenge for Anesthesiologists. This paper aimed at discussing why and when to induce anesthesia in UAl children.

CONTENTS: Preoperative clinical history, factors contributing to peri and postoperative complications and the type of surgery and anesthetic technique favoring such complications are highlighted.

CONCLUSIONS: The understanding of post-UAI respiratory tract changes, of the importance of accurately evaluating the severity of symptoms, of factors contributing to complications and of the best anesthetic technique will allow for the choice of patients at the lowest risk to develop perioperative complications.

Key Words: ANESTHESIA, Pediatric; DISEASES: upper airway infection

\section{INTRODUÇÃO}

A nestesiar, com segurança, criança com infecção de vias aéreas superiores constitui um dos grandes desafios do anestesiologista.

Vários estudos demonstram que, em pacientes pediátricos, a presença de infecção de vias aéreas superiores aumenta o risco de complicações respiratórias no período per-operatório ${ }^{1-7}$.

\footnotetext{
* Recebido do (Received from) CET/SBA do Departamento de Anestesiologia da Faculdade de Medicina de Botucatu (FMB-UNESP), Botucatu, $S P$

1. Professora Adjunta Livre Docente do CET/SBA do Departamento de Anestesiologia da FMB-UNESP

2. Professora Titular do CET/SBA do Departamento de Anestesiologia da FMB-UNESP
}

Endereço para correspondência (Correspondence to)

Profa. Dra. Eliana Marisa Ganem

Departamento de Anestesiologia da FMB-UNESP

Distrito de Rubião Junior

18618-970 Botucatu, SP

E-mail: eganem@fmb.unesp.br

Apresentado (Submitted) em 23 de setembro de 2002 Aceito (Accepted) para publicação em 04 de novembro de 2002

(C) Sociedade Brasileira de Anestesiologia, 2003
A criança que apresenta coriza pode ser portadora de condição infecciosa benigna, como rinite sazonal ou vasomotora e, nestes casos, a cirurgia pode ser realizada. Contudo, a coriza pode ser pródromo de doença ou processo infeccioso efetivo que torna necessária a suspensão do ato anestésico-cirúrgico.

O objetivo deste artigo é discutir qual criança com infecção de vias aéreas superiores pode ser anestesiada e quando.

\section{A CRIANÇA COM INFECÇÃO DE VIAS AÉREAS SUPERIORES E A ANESTESIA}

Aproximadamente $20 \%$ a $30 \%$ de todas as crianças submetidas a procedimentos cirúrgicos apresentam coriza em boa parte do ano e devem ser avaliadas de maneira individual quanto à possibilidade de se realizar ou não uma cirurgia eletiva ${ }^{8}$.

Estudo ${ }^{9}$ concluiu que crianças com infecção de vias aéreas superiores ativa ou com infecção de vias aéreas superiores recente (até quatro semanas após o início do quadro) possuem risco aumentado de desenvolver complicações respiratórias no período per-operatório. A incidência e gravidade dessas complicações são as mesmas, tanto para o quadro ativo como para o recente. 
A probabilidade de aparecimento dessas complicações aumenta se houver, concomitantemente, história prévia de doenças que cursam com hiperreatividade das vias aéreas, cirurgias que envolvem as vias aéreas superiores, pacientes com história de prematuridade, crianças expostas a ambiente com fumaça de cigarro e aquelas que apresentam congestão nasal ou secreção nasal copiosa ${ }^{9}$.

Skolnick e col. ${ }^{10}$ mostraram que o risco de complicações respiratórias foi maior nas crianças com quadro ativo de infecção de vias aéreas superiores e nos primeiros dias após a mesma, risco que permaneceu elevado por mais de seis semanas após o aparecimento dos sintomas. Embora o mecanismo exato desencadeante dessas complicações não seja claro, danos morfológicos do epitélio respiratório e da mucosa após infecção respiratória viral podem sensibilizar as vias aéreas aos gases anestésicos que são potencialmente irritantes e aumentar as secreções. Isto resultaria em ativação de receptores e em contração da musculatura lisa do trato respiratório ${ }^{11,12}$. A reatividade das vias aéreas pode estar alterada por até 6 a 8 semanas após infecção de vias aéreas superiores $^{13-15}$.

A infecção viral recente é fator de risco para complicações pulmonares durante a anestesia, especialmente se esta é realizada com intubação traqueal. As complicações mais freqüentemente observadas são tosse, laringoespasmo, broncoespasmo e atelectasia ${ }^{16,17}$.

Crianças que apresentam infecção de vias aéreas superiores e foram submetidas à anestesia geral apresentam diminuição nas reservas de $\mathrm{O}_{2}{ }^{18,19}$ e alta incidência de laringoespasmo (cinco vezes mais elevada) ${ }^{2}$ e de broncoespasmo (dez vezes mais elevada) ${ }^{3}$.

A incidência de tosse, laringoespasmo, broncoespasmo e dessaturação da hemoglobina aumentou de duas a sete vezes nos pacientes que foram anestesiados em vigência de infecção de vias aéreas superiores e onze vezes naqueles que necessitaram de intubação traqueal ${ }^{1}$.

Outro estudo demonstrou que crianças que tiveram a traquéia intubada, quer pela via oral ou nasal, apresentaram maior incidência de complicações respiratórias que aquelas cujo acesso às vias aéreas foi conseguido com auxílio de máscara laríngea e de máscara facial ${ }^{20}$. Nesta pesquisa, a máscara laríngea proporcionou via aérea segura, sem irritá-la, o que é fundamental na criança com infecção de vias aéreas superiores ${ }^{21}$.

Os pacientes que roncam ${ }^{20}$, que apresentam tosse produtiva e congestão nasal ${ }^{9,20}$, também estão mais propensos a complicações no período per-operatório. A presença de roncos e de congestão nasal reforça a importância da obstrução das vias aéreas superiores como fator de previsão de complicações durante a anestesia em crianças ${ }^{20}$. É importante que se investigue, durante a avaliação pré-anestésica, se a criança tem história de apnéia do sono ou se ela ron$\mathrm{ca}^{20}$.

As crianças que apresentam rinorréia desenvolvem curtos períodos de apnéia durante a anestesia, antes mesmo que haja diminuição da saturação da hemoglobina pelo oxigênio $\left(\mathrm{SpO}_{2}\right)$, e a idade do paciente está diretamente relacionada ao tempo no qual a dessaturação aparece, ou seja, quanto mais nova a criança, mais rapidamente ela dessatura ${ }^{18}$. As crianças com infecção de vias aéreas superiores também apresentam diminuição transitória na $\mathrm{SpO}_{2}$ no período per-operatório ${ }^{5,19}$. A função pulmonar pode estar alterada por até 8 semanas após um episódio de infecção de vias aéreas superiores.

Alguns autores demonstraram que as infecções virais do trato respiratório superior podem se estender às vias aéreas inferiores, mesmo nas afeções não complicadas ${ }^{22}$. Esses autores encontraram alterações ventilatórias restritivas e redução na pressão arterial de oxigênio $\left(\mathrm{PaO}_{2}\right)$ em indivíduos com infecção viral não complicada, secundária à atelectasia, bronquiolite e pneumonia intersticial.

Ainflamação aguda das pequenas vias aéreas pode alterar a distribuição da ventilação o suficiente para comprometer as trocas gasosas ${ }^{23}$. A produção de surfactante também pode estar alterada, em áreas salpicadas, levando a instabilidades regionais das pequenas vias aéreas ${ }^{24}$.

Após virose respiratória, a hiperreatividade temporária das vias aéreas, que perdura por semanas após a resolução do quadro, parece ser decorrente de alteração do controle dos nervos parassimpáticos. A lesão epitelial determinada pelo agente etiológico também contribui para a hiperreatividade brônquica ${ }^{13}$. Existem evidências de que o epitélio pode modular a função dos músculos lisos das vias aéreas, liberando substâncias que têm atividades excitatórias e inibitórias ${ }^{25}$. A lesão epitelial determinada pelo agente viral aumentaria a potência contrátil em resposta às taquicininas, que são neuropeptídeos encontrados nas fibras $\mathrm{C}$ das vias respiratórias 16. A substância $P$ é uma taquicinina que, dentre outras ações, estimula a contração da musculatura lisa das vias aéreas.

Mesmo pacientes sem doenças respiratórias prévias podem desenvolver hiperreatividade de vias aéreas ${ }^{14}$ e capacidade de difusão anormal ${ }^{26}$ durante infecções virais. Isto é preocupante quando há necessidade de intubação traqueal, porque o tubo em contato com a traquéia pode desencadear reflexo de broncoconstrição ${ }^{27}$, mediado quimicamente ou mediado pelo vago ${ }^{13}$.Está descrito que pacientes com doença respiratória preexistente (asma) têm exacerbação da doença durante infecção de vias aéreas superiores ${ }^{28}$.

Além disso, embora todos se refiram à doença como infecção de vias aéreas superiores, as vias aéreas inferiores podem estar envolvidas, mesmo em pacientes assintomáticos 29

Como nem toda coriza é resultado de infeção respiratória viral, a história clínica deve ser o objetivo principal na investigação pré-operatória. Devem ser pesquisados a freqüência e o tipo da coriza, a presença ou ausência de tosse, a associação com faringite, espirros, febre, indisposição e, em crianças pequenas, as mudanças no comportamento alimentar. Ao exame físico deve-se procurar estertores nos pulmões. 
Radiografia de tórax e contagem de células brancas também são realizadas.

A história da infecção de vias aéreas superiores, assim como a opinião dos pais sobre ela, são fatores importantes na decisão de realizar anestesia para procedimentos eletivos. Schreiner e col. ${ }^{6}$ observaram que a opinião dos pais sobre os sintomas da criança foi associada, com maior precisão, ao risco de laringoespasmo do que a avaliação das características da infecção de vias aéreas superiores.

Saturação normal em ar ambiente não assegura curso per-operatório suave. A necessidade de intubar e manipular as vias aéreas é importante na decisão da conduta a ser tomada. Tradicionalmente, se a coriza é clara e não há sinais de comprometimento sistêmico, recomenda-se que se realize a cirurgia, desde que se evite a intubação traqueal.

Schreiner e col. ${ }^{6}$ pesquisaram mais de 15.000 crianças submetidas a procedimentos ambulatoriais e estimaram que se todas as crianças com sintomas de infecção de vias aéreas superiores tivessem a cirurgia adiada, 2.000 crianças teriam a cirurgia cancelada para se evitar apenas 15 episódios de laringoespasmo. Na prática, somente $0,5 \%$ dos pacientes envolvidos neste estudo realmente deveriam ter sua cirurgia adiada.

Coté ${ }^{30}$ tem como conduta não suspender a anestesia de crianças com infecção de vias aéreas superiores não complicada. Rolf e Coté ${ }^{7}$ sustentam que os breves períodos de dessaturação $\left(\mathrm{SaO}_{2} 95 \%\right.$ em tempo menor que $\left.60 \mathrm{~s}\right)$ observados nestes pacientes são facilmente tratados, não determinam seqüelas e, portanto, não contra-indicam a anestesia. Dessa forma, a relação risco/benefício de se realizar o procedimento deve ser pesada após discussão com os pais e com os cirurgiões.

É prudente que se evite a intubação traqueal, desde que possível, porque diminui a incidência de broncoespasmo ${ }^{31}$.

Para realização de cirurgia em pacientes com infecção de vias aéreas superiores, os procedimentos ambulatoriais são os mais aconselháveis, pois a criança internada pode-se infectar com outro patógeno na enfermaria ou pode infectar uma criança com o sistema imunológico debilitado por outra doença.

A seleção do agente anestésico é fundamental. O tiopental foi associado à maior incidência de complicações respiratórias no período per-operatório, seguido pelo halotano e sevoflurano. O propofol, porque deprime os reflexos laríngeos e diminui as respostas das vias aéreas por promover relaxamento da musculatura lisa dos brônquios ${ }^{20,32,33}$, é excelente escolha nesse grupo de pacientes.

A decisão de anestesiar uma criança com infecção de vias aéreas superiores, para cirurgias eletivas, é individual, com avaliação criteriosa da gravidade dos sintomas e da necessidade de se intubar a via aérea. Deve-se, também, selecionar o agente anestésico mais seguro e o anestesiologista deve estar habituado a anestesiar criança com esta afecção ${ }^{20}$.

\section{Patient with Upper Airway Infectious Disease. When to Induce Anesthesia?}

Eliana Marisa Ganem TSA, M.D., Norma Sueli Pinheiro Módolo TSA, M.D., Yara Marcondes Machado Castiglia TSA, M.D.

\section{INTRODUCTION}

Anesthesia in children with upper airway infection (UAI) is a major challenge for Anesthesiologists.

Several studies have shown that the presence of upper airway infection in pediatric patients increases the risk for perioperative respiratory complications ${ }^{1-7}$.

Children with coryza may have a benign infection, such as seasonal or vasomotor rhinitis and may, therefore, be submitted to surgical procedures. However, coryza may be the prodrome of an effective infectious disease or process requiring the postponement of the anesthetic-surgical procedure.

This paper aimed at discussing when and why to induce anesthesia in children with upper airway infection.

\section{UPPER AIRWAY INFECTION CHILDREN AND ANESTHESIA}

Approximately $20 \%$ to $30 \%$ of all children submitted to surgical procedures present with coryza for a large part of the year and should be individually evaluated for the possibility of performing or not an elective surgery ${ }^{8}$.

A recent study ${ }^{9}$ has concluded that children with active upper airway infection or recent upper airway infection (up to four weeks after initial symptoms), are at increased risk for developing perioperative respiratory complications. Incidence and severity of such complications are the same both for active and recent infection.

The probability of such complications increases if there is a concomitant previous history of diseases with airway hyper-reactivity, surgeries involving upper airways, prematurity, exposure to cigarette smoke and nasal congestion or abundant nasal secretion ${ }^{9}$.

Skolnick et al. ${ }^{10}$ have shown that the risk for respiratory complications was increased in children with active upper airway infection and during the first days following it, and the risk was kept high for more than six weeks after beginning of symptoms. Although the triggering mechanism for such complications is not clear, morphological respiratory epithelium and mucosal damage after viral respiratory infection may sensitize airways to anesthetic gases which are potentially irritating and may increase secretions. This would result in receptors activation and respiratory tract smooth muscle contraction ${ }^{11,12}$. Airways reactivity may be abnormal for up to 6 to 8 weeks after upper airway infections ${ }^{13-15}$.

Recent viral infection is a risk factor for pulmonary complications during anesthesia, especially when it is induced with tra- 
cheal intubation. Most common complications are cough, laryngospasm, bronchospasm and atelectasis ${ }^{16,17}$.

Children with upper airway infection submitted to general anesthesia have decreased $\mathrm{O}_{2}$ reserves ${ }^{18,19}$ and a high incidence or laryngospasm (five times higher) ${ }^{2}$ and bronchospasm (ten times higher) ${ }^{3}$.

The incidence of cough, laryngospasm, bronchospasm and hemoglobin desaturation was increased two to seven fold in patients anesthetized in the presence of upper airway infection, and 11 fold in those needing tracheal intubation ${ }^{1}$.

A recent study has shown that intubated children, by the oral or nasal route, had a higher incidence of respiratory complications as compared to those in whom airway access was obtained with the help of laryngeal and facial masks ${ }^{20}$. In this study, the laryngeal mask has provided safe airway without irritating it, which is critical for upper airway infection children $^{21}$.

Patients who snore ${ }^{20}$, have productive cough and nasal congestion ${ }^{9,20}$ are also more prone to perioperative complications. The presence of snoring and nasal congestion reinforces the importance of upper airway obstruction as a factor to predict complications during pediatric anesthesia ${ }^{20}$. It is important to investigate during preanesthetic evaluation if the child has a history of sleep apnea or snoring ${ }^{20}$.

Children with rhinorrhea develop short apnea periods during anesthesia even before oxygen hemoglobin saturation decrease $\left(\mathrm{SpO}_{2}\right)$, and patients' age is directly related to the moment in which desaturation appears, that is, the younger the child, the faster the desaturation ${ }^{18}$.

Children with upper airway infection have transient perioperative $\mathrm{SpO}_{2}$ decrease ${ }^{5,19}$. Pulmonary function may be abnormal up to 8 weeks after an episode of upper airway infection.

Some authors have shown that viral upper respiratory tract infections may reach lower airways even in non complicated cases ${ }^{22}$. These authors have found restrictive ventilatory changes and arterial oxygen pressure decrease $\left(\mathrm{PaO}_{2}\right)$ in individuals with non complicated viral infection secondary to atelectasis, bronchiolitis and interstitial pneumonia.

Acute small airways infection may change ventilation distribution enough to impair gas exchanges ${ }^{23}$. Surfactant production may also be changed in spotted areas, leading to regional instability of small airways ${ }^{24}$. After viral respiratory infection, transient airway hyper-reactivity, which lasts for weeks after resolution, seems to be a consequence of parasympathetic nerves control change. Epithelial injury caused by the etiologic agent also contributes for bronchial hyper-reactivity ${ }^{13}$. There are evidences that the epithelium may modulate airway smooth muscles function, releasing substances with excitatory and inhibitory activity ${ }^{25}$. Virus-induced epithelial injury would increase contractile strength in response to tachykinins, which are neuropeptides found in airways $C$ fibers $^{16}$. P substance is a tachykinin which, among other actions, stimulates airway smooth muscles contraction.

Even patients without previous respiratory disease may develop airway hyper-reactivity ${ }^{14}$ and abnormal diffusion capacity ${ }^{26}$ during viral infections. This is worrisome when there is the need for tracheal intubation because the tube in contact with the trachea may trigger bronchoconstriction reflex ${ }^{27}$ chemically mediated or mediated by the vagus ${ }^{13}$. It has been described that patients with preexisting respiratory disease (asthma) have their disease exacerbated during upper airway infection ${ }^{28}$.

In addition, although the name upper airway infection, lower airways may also be involved, even in asymptomatic patients $^{29}$.

Since not all coryza is the result of viral respiratory infection, clinical history should be the major objective during preanesthetic evaluation. Frequency and type of coryza, presence or absence of cough, association with faryngitis, sneezing, fever and discomfort should be investigated, in addition to dietary behavior changes in small children. Lung rales should be looked for during physical evaluation. Chest X-rays and white cell count should also be performed.

History of upper airway infection and parents' opinion about the disease are important factors in the decision of inducing anesthesia for elective procedures. Schreiner et al. ${ }^{6}$ have observed that parents' opinion about the symptoms has been more precisely associated to the risk for laryngospasm than the evaluation of upper airway infection characteristics. Normal saturation in room air does not assure a smooth perioperative period. The need to intubate and manipulate airways is important in the decision of the approach to be used. Traditionally, if coryza is light and there are no evidences of systemic involvement, surgery is recommended provided tracheal intubation is avoided.

Schreiner et al. ${ }^{6}$ have investigated more than 15000 children submitted to outpatient procedures and have estimated that, if all children with upper airway infection symptoms had their surgeries postponed, 2000 children would have had their surgeries cancelled to prevent just 15 episodes of laryngospasm. In practice, only $0.5 \%$ of patients involved in this study should have had their surgeries postponed.

Coté's approach ${ }^{30}$ is not to counterindicate anesthesia in children with non complicated upper airway infection. Rolf and Coté ${ }^{7}$ state that brief desaturation episodes $\left(\mathrm{SaO}_{2} 95 \%\right.$ in less than 60 seconds) observed in those patients are easily treated and do not leave sequelae, thus not counterindicating anesthesia. This way, the risk/benefit ratio of performing the procedure should be considered after discussions with parents and surgeons.

It is prudent to avoid tracheal intubation whenever possible to decrease the incidence of bronchospasm ${ }^{31}$.

Outpatient procedures are the best for patients with upper airway infection because hospitalized children may be infected by other pathogen in the ward or may infect a child with the immune system impaired by other disease.

The choice of the anesthetic agent is critical. Thiopental has been associated to a higher incidence of perioperative respiratory complications, followed by halothane and sevoflurane. Propofol, for depressing laryngeal reflexes and decreasing airway responses by promoting bronchial smooth muscles relaxation ${ }^{20,32,33}$, is an excellent choice for this group of patients. 
The decision of inducing anesthesia in children with upper airway infection submitted to elective surgeries is individual, with a careful evaluation of symptoms severity and of the need to intubate. The safer anesthetic agent should be also selected and the anesthesiologist must be used to anesthetizing children with such disease ${ }^{20}$.

\section{REFERÊNCIAS - REFERENCES}

01. Cohen MM, Cameron CB - Should you cancel the operation when a child has an upper respiratory tract infection? Anesth Analg, 1991;72:282-288.

02. Olsson GL, Hallen B - Laryngospasm during anaesthesia: a computer-aided incidence study in 136.929 patients. Acta Anaesthesiol Scand, 1984;28:567-575.

03. Olsson GL - Bronchospasm during anaesthesia: a computer-aided incidence study in 136.929 patients. Acta Anaesthesiol Scand, 1987;31:244-252.

04. Nascimento Jr P, Neves LBJ, Módolo NSP et al - Complicações respiratórias em crianças submetidas a anestesia geral. Rev Bras Anestesiol, 2000;50:345-349.

05. DeSoto H, Patel RI, Soliman IE et al - Changes in oxygen saturation following general anesthesia in children with upper respiratory signs and symptoms undergoing otorhynological procedures. Anesthesiology, 1988;68:267-269.

06. Schreiner MS, O'Hara I, Markakis DA et al - Do children who experience laryngospasm have an increased risk of upper respiratory tract infection? Anesthesiology, 1996;85:475-480.

07 . Rolf N, Coté CJ - Frequency and severity of desaturation events during general anesthesia in children with and without upper respiratory infections. J Clin Anesth, 1992;4:200-203.

08. Hannallah RS - What's new in pediatrics? Probl Anesth, 1999;11:95-105.

09. Tait AR, Malviya S, Voepel-Lewis T et al - Risk factors for perioperative adverse respiratory events in children with upper respiratory tract infections. Anesthesiology, 2001;95:299-306.

10. Skolnick ET, Vomvolakis MA, Buck KA - A prospective evaluation of children with upper respiratory infections undergoing a standardized anesthetic and incidence of respiratory events. Anesthesiology, 1998;89:A1309.

11. Jacoby DB, Hirshman CA - General anesthesia in patients with viral respiratory infections: an unsound sleep? Anesthesiology, 1991;74:969-972.

12. Little JW, Hall WJ, Douglas RG et al - Airway hyperactivity and peripheral airway dysfunction in influenza A infection. Am Rev Respir Dis, 1978;118:295-303.

13. Empey DW, Laitenen LA, Jacobs I et al - Mechanisms of bronchial hyperreactivity in normal subjects after upper respiratory tract infection. Am Rev Respir Dis, 1976;113:131-139.

14. Aquilina At, Hall WJ, Douglas RG et al - Airway reactivity in subjects with viral respiratory infections: the effects of exercise and cold air. Am Rev Respir Dis, 1980;122:3-10.

15. Tait AR, Pandit UA, Voepel-Lewis T et al - Use of the laryngeal mask airway in children with upper respiratory tract infections: a comparison with endotracheal intubation. Anesth Analg, 1998;86:706-711.

16. Martin LD - Anesthetic implications of an upper respiratory infection in children. Ped Clin North Am, 1994;41:121-130.

17. Williams OA, Hills R, Goddaid JM - Pulmonary collapse with respiratory tract syntoms. Anaesthesia, 1992;47:411-413.

18. Kinouchi K, Tanigami $\mathrm{H}$, Tashiro $\mathrm{C}$ et al - Duration of apnea in anesthetized infants and children required for desaturation of hemoglobin to $95 \%$. The influence of upper respiratory infection. Anesthesiology, 1992;77:1105-1107.

19. Levy L, Pandit UA, Rangel GI et al - Upper respiratory tract infections and general anaesthesia in children. Anaesthesia, 1992;47:678-682.

20. Parnis SJ, Barker DS, van der Walt JH - Clinical predictors of anaesthetic complications in children with respiratory tract infections. Paediatr Anaesth, 2001;11:29-40.

21. van der Walt $\mathrm{JH}$, - Anaesthesia in children with viral respiratory tract infections. Paediatr Anaesth, 1995;5:257-262.

22. Johanson Jr JR, Pierce A, Sanford JP - Pulmonary function in uncomplicated influenza. Am J Respir Dis, 1969;100:141-150.

23. Hogg IC, Macklem PT, Thurlbeck WM - Site and nature airway obstruction in chronic obstructive lung disease. N Eng J Med, 1968:1:355-363.

24. Picken JJ, Niewochner DE, Chester EH - Prolonged effects of viral infection's on upper respiratory tract upon small airways. Am J Med, 1971;52:738-745.

25. Fryer AD, Jacoby DB - Muscarinic receptors and control of airway smooth muscle. Am J Respir Crit Care Med, 1998;158: S154-160.

26. Cate TR, Roberts JS, Russ MA et al - Effects of common colds on pulmonary function. Am Rev Respir Dis, 1973;108:858-865.

27. Nadel JA, Widdicombe JC - Reflex effects of upper airway irritation on total lung resistance and blood pressure. J Appl Physiol, 1962;28:861-865.

28. Welliver RC - Upper respiratory infections in asthma. J Allergy Clin Immunol, 1983;72:431-446.

29. Collier AM, Pimmel RL, Hasselblad V et al - Spirometric changes in normal children with respiratory infections. Am Rev Respir Dis, 1978;117:47-53.

30. Coté CJ - Preoperative preparation and premedication. $\mathrm{Br} \mathrm{J}$ Anaesth, 1999;83:16-28.

31. Cohen MM, Cameron CB, Duncan PG - Pediatric anesthesia morbidity and mortality in the perioperative period. Anesth Analg, 1990;70:160-167.

32. Ouedraogo N, Roux E, Forestier F et al - Effects of intravenous anesthetics on normal and passively sensitized human isolated airway smooth muscle. Anesthesiology, 1998;88:317-326.

33. Cheng EY, Mazzeo AJ, Bosnjak ZJ et al - Direct relaxant effects of intravenous anesthetics on airway smooth muscle. Anesth Analg, 1996;83:162-168.

\section{RESUMEN}

Ganem EM, Módolo NSP, Castiglia YMM - El Paciente con Infección de Vías Aéreas Superiores ¿Cuando Anestesiar?

JUSTIFICATIVA Y OBJETIVOS: Anestesiar, con seguridad, a un niño con infección de vías aéreas superiores (IVAS) constituye uno de los grandes desafíos del anestesiologista. La finalidad de este articulo es discutir la validad de anestesiar y cuando anestesiar a un niño con IVAS.

CONTENIDO: Están resaltados la importancia de la historia clínica en la investigación pré-operatoria, los factores que contribuyen para el aparecimiento de complicaciones en el per y en el pós-operatorio, así como el tipo de cirugía y la técnica anestésica que favorecen estas complicaciones.

CONCLUSIONES: El conocimiento de las alteraciones en el tracto respiratorio que acontecen después de IVAS, de la importancia de la evaluación correcta de la gravedad de los síntomas, de los factores que pueden contribuir para el aparecimiento de complicaciones y de la mejor técnica anestésica posibilita la selección de pacientes con menor risco de desarrollar complicaciones en el período per-operatorio. 